\title{
"I FORGOT WHAT IT IS": THE ENACTMENT OF 2013 CURRICULUM IN EFL CLASSROOM
}

\author{
Susmalinda Misbah \\ susmalinda.13399@gmail.com \\ English Education Department, Faculty of Teacher Training and Education, Universitas \\ Mataram, Indonesia \\ Untung Waluyo \\ untungwaluyo@unram.ac.id \\ Graduate Program of English Language Education, Faculty of Teacher Training and \\ Education, Universitas Mataram, Indonesia \\ Khusnul Khotimah* \\ khusnul_pena@unram.ac.id \\ English Education Department, Faculty of Teacher Training and Education, Universitas \\ Mataram, Indonesia
}

\begin{abstract}
To date, the 2013 curriculum has been implemented for almost a decade. But this latest curriculum has not been well-implemented due to many obstacles. Accordingly, plethora studies have been extensively carried out to refine the praxis. However, the investigation of this area in EFL class in Junior High Schools is underexplored. Thus, this study was carried out to fill this void. This research study aimed to investigate the problems in enacting 2013 Curriculum, to reveal the hindering factors, and to showcase how English teachers cope with those problems. Grounded in a case study, nine English teachers of state junior high schools were recruited. Data were collected through observations, documentations, and interviews. The findings confirmed that teachers experienced some delinquent setback in translating curriculum into instruction. This was related to how they teach using suggested teaching stages, integrate intended domains of competence, and conduct authentic assessment. Furthermore, students' lack of motivation and autonomy was also a sizeable impediment. In relation to this, some hindering factors and teachers' endeavors to cope with the abovementioned problems were also elaborated systematically. To end this article, some practical recommendations were proposed accordingly.
\end{abstract}

Keywords: EFL class, EFL teachers, problem, hindering factors, scientific approach, 2013 Curriculum

\section{Sari}

Kurikulum 2013 telah diterapkan selama hampir satu dekade sejak awal 2013. Namun kurikulum terbaru ini masih belum dilaksanakan dengan baik karena banyak kendala di 
lapangan. Merespon hal ini, penelitian dengan topik bahasan terkait telah banyak dilakukan. Akan tetapi, penyelidikan pada topik ini di sekolah menengah pertama belum banyak dieksplorasi. Oleh karena itu, penelitian ini dilakukan untuk mengisi kekosongan yang dimaksud. Studi penelitian ini bertujuan untuk menyelidiki masalah yang dihadapi oleh guru Bahasa Inggris dalam melaksanankan Kurikulum 2013, mengungkapkan faktor-faktor penghambat yang menyebabkan masalah tersebut, dan menunjukkan bagaimana guru mengatasi masalah tersebut. Berbasis studi kasus, penelitian ini melibatkan 9 guru dari tiga sekolah negeri menengah tingkat awal .Data dikumpulkan melalui observasi, dokumentasi dan wawancara. Temuan menunjukkan bahwa guru- guru Bahasa Inggris mengalami kesulitan dalam mengaplikasikan konsep kurikulum 2013 ke dalam proses pembelajaran di dalam kelas dalam hal tahapan pembelajaran, mengintegrasikan cakupan kompetensi, dan aplikasi asesemen yang autentik. Lemahnya tingkat motivasi dan kemandirian siswa juga merupakan kendala yang serius. Berkaitan dengan hal ini, beberapa faktor penghambat dan upaya mengatasi masalah tersebut juga dijelaskan secara terstruktur. Artikel ini ditutup dengan beberapa rekomendasi.

Katakunci :Masalah dan fator penghambat, Kurikulum 2013, Pengajaran Bahasa Inggris, Pendekatan saintifik.

Received 2020-09-13 accepted 2020-09-30 published 2020-09-30

APA Citation: Misbah, M., Waluyo,U., \& Khotimah, K. (2020). "I FORGOT WHAT IT IS": THE ENACTMENT OF 2013 CURRICULUM IN EFL CLASSROOM. Research and Innovation in Language Learning 3(3), pp. 234252 http://dx.doi.org/10.33603/rill.v3i3.4147

\section{Introduction}

Indonesian curriculum has undertaken changes many times prior to the enactment of 2013 Curriculum starting from (1) Curriculum 1975; (2) Curriculum 1986; (3) Curriculum 1994; (4) Curriculum 2004; (5) school based curriculum (SBC) which refers to the National Education Standards, and then (6) Curriculum 2013 (Prihantoro, 2015). The development of the curriculum is regarded as the changing of people's needs, technology, thinking, as well as market challenges (Widodo, 2015). The 2013 curriculum gives a new transformation in the teaching-learning activities. It covers some stages of teaching facilitating students to be more active and engaged in the instruction. This curriculum is used in every kind of subjects in school that focuses on achieving students' competencies and character-building (Kemendikbud, 2013). There are four 
aspects of competences expected to succeed in the implementation of the 2013 curriculum called cognitive domains (spiritual, attitude, knowledge, and skills). This newest curriculum entails the students to be fully involved in the process of learning; this is known as Student-Cantered Learning (henceforth, SCL).

In English Language Teaching (ELT), SCL has been defined in many ways, Felder and Brent (1996, p. 43) termed SCL as "a broad teaching approach that includes substituting active learning for lectures, holding students responsible for their learning, and using self-paced and/or cooperative (team-based) learning." Learning process is more centred to students to find, construct, and make meaning to the new knowledge. Further, Jacobs, Renandya, \& Power (2016) synthesizes 10 elements of SCL in which emphasizing on the position of teachers and students, interaction, learning autonomy, meaningful learning, curricular integration, diversity, thinking skills, alternative assessment, learning climate, and motivation. SCL as suggested by 2013 curriculum requires teachers to provide opportunities for students to meaningfully talk and listen, write, read, and reflect on the content, ideas, issues, and concern of an academic subject. It can be considered as an "active learning," which aims to help students learn more independently. Thus, teacher cannot be the superior pouring knowledge and new insight to students' head (Jacobs \& Renandya, 2016). As such, CLT provides the students with new skills (Thanh, 2010) like independence, creativeness, activeness, and cooperativeness required by the labour market.

In this connection, English teachers in 2013 curriculum are suggested to follow a number of stages, what is so called 'scientific approach' in conducting the teaching learning process. The first stage is observation. In this stage, teachers build students' attention toward materials being learned. Students are observing the details of the materials. Second phase is the questioning stage. Here, teachers encourage students to think of research questions related to observed materials. Exploring and associating are the follow up of the questioning stage. In those steps, students collect information from various sources, and then do series of activities covering reading, analysing, synthesizing, and conducting group discussion. Going through all of the stages, the teachers play their roles as facilitators, organizers, and controllers for what students do 
(Regulation of the Ministry of Education and Culture of the Republic of Indonesia No. 81a, 2013). In the last stage, communicating, the teachers assess the students while they are presenting the result of their work. This is followed by giving reinforcement to the students. Here the teachers play their roles as assessors and prompters and/or motivators. In short, in EFL classroom, students need to use their curiosity and learning force to learn English by doing series of activities; observing, questioning, exploring, associating, and communicating. These series can be done through discovery learning, inquiry learning, problem-based learning, and project-based learning.

In practice, English teachers' duties to conduct teaching and learning activities under the 2013 Curriculum are complex in nature. To be successful in applying certain curriculum including 2013 curriculum, teachers are expected to have a verbal ability, content knowledge, pedagogical knowledge, ability to use a range of teaching strategies skilfully, enthusiasm for teaching the subjects (Natasa, 2011), adequate understanding about the nature of scientific approach, sense of peer collaboration, and creativity (Wahyudin \& Sukyadi, 2015). In responding to a new curriculum, teachers need to make some adjustment and adaptation, starting from preparing, implementing, and evaluating the lesson. With such a change of nature, it is predicted that teachers in the field may face problems in implementing he 2013 curriculum in the classroom.

Empirically, a number of research studies confirmed this prediction, for instance Darsih (2014), Retnawati, Hadi, \&Nugraha (2016), and Suratri, (2018) reported that the most problematic issue faced by teachers was the application of authentic assessment as suggested by the 2013 curriculum. This happened due to inadequate learning time and insufficient understanding about the assessment system. Furthermore, other teachers were also reported to experience hurdles in conducting the learning using the steps of scientific approach due to their lack of knowledge and skills (Oktavianti, 2018) and students' passive participation (Ekawati, 2016). The similar finding was also reported by Wahyudin \& Sukyadi (2015) in which English teaches seemed could not effectively apply the scientific approach. However, this approach was found gave positive impact on students' participation, critical thinking, and confidence. Zaim (2017) also reported that teachers experienced complexities in observing and questioning stages of scientific 
approach. In a wider scope, Ahmad (2014) found that schools and teachers possessed some challenges in enacting 2013 curriculum in term of class size, learning process, teaching facilities, and untimely of in service training. In contrast, Ratnaningsih (2017) revealed different finding compared to the abovementioned scholarly articles. Geared from her case study in a Junior School in Bandung, western part of Indonesia, she argued that teachers in her study could implement the scientific approach well in their English language Teaching.

Despite such reports, the recent study found that there were two major benefits that students could take from the implementation of the 2013 curriculum in EFL process. First, the 2013 curriculum could promote an independent learning, and second, it stimulated students to be creative learners (Sulistyo, et al, 2020). Although there have been ample of reports on the implementation of 2013 Curriculum, current efforts to scrutinize the underlying problems and challenges faced by EFL teachers in the field have not been much undertaken yet in eastern parts of Indonesia, especially in the level of junior high schools. Thus, problems or hurdles concerning the implementation of 2013 Curriculum remain unknown and underexplored. Ultimately, the present study was carried out to fill this gap and to enrich the body of knowledge of this particular topic in the city of Mataram, the eastern part of Indonesia.

Accordingly, this research study aims to (a) find out the problems encountered by EFL teachers in deploying the teaching methods suggested by the 2013 Curriculum, (b) to reveal the hindering factors causing the emerging problems, and (c) to explain how teachers cope with the reported problems.

\section{Methods}

This study employed a descriptive qualitative research in the form of case study. In a case study, researchers should understand how and why contemporary events, problems, and situations in ways that do not require control over those events or issues (Yin, 2018). The present study was conducted in three state junior high schools in Mataram. Those places were selected because they had implemented the scientific approach since the launching of this particular curriculum. Nine teachers teaching in grades $7^{\text {th }}, 8^{\text {th }}, 9^{\text {th }}$ in three state junior high schools in Mataram were recruited. The reason for involving 
the English teachers from different schools was to find a broad perspective about the problems they faced in applying the teaching methods of the 2013 curriculum. By involving three English teachers in each grade from the respective schools, the researcher assumed that the information obtained may have varied.

Those nine participants ( 2 male teachers and 7 female teachers), aged around 35 to 45 years old, had teaching experiences for more than 5 years. 8 of them earned bachelor degree and 1 obtained master degree in ELT. In recruiting them, the researchers sent consent letters to the principals of those three schools asking for permission and access to the teachers to conduct the study. In response to this query, the principals replayed positively and gave the official access to these nine teachers. Practically, even though these nine teachers were assigned by the principals to be the participants of this study, the researchers were aware about their right to decide their involvement. These nine teachers were then orally informed the nature of this research and information whether the participation of this study followed the voluntary basis in which they had the right to partake or vice versa. They also had the absolute merit to withdraw their participation anytime even in the middle of data collection. To keep their confidentiality, their names were made pseudonyms. This also applied to the schools' names.

The data were collected from observations, documentation, and interviews. The observations were conducted nine times in the teaching-learning process in the classroom. Whereby, each respondent was observed within two-hour time. Classroom observations were chosen as they allowed information to be recorded and enabled the actual behaviour of the teachers and students to be studied. The researchers observed the whole learning and teaching activities and took the notes in the observation sheets regarding how the teachers implemented the scientific approach in English teaching based on the 2013 curriculum, especially in the essential of the teaching methods suggested by the 2013 curriculum.

The process of documentation was done by sighting and analysing the lesson plan that the teachers used during teaching-learning process in the class. In analysing data from the documentation, the conformity of teachers' lesson plans to the principles of the 
scientific approach had been checked using the government lesson plans' guidelines. In addition to observations and documentation, researchers also recruited participants to have series of interviews in purpose of gathering sufficient data in the form of semistructured interviews. The semi-structured interview contains a mix of closed-ended and open-ended questions and covers fairly specific topics or themes (Kielmann et al., 2012). The researchers made the list of questions related to problems in teaching activity using a scientific approach as the guideline and conducted the interviews in the places and times that were mutually convenient for both researchers and participants. Each respondent was interviewed for ten to fifteen minutes. Data were recorded using Smartphone recorder with participants' agreement.

To strengthen the confirmability of the data, the researchers used triangulation. Triangulation is a data validity investigation technique that takes advantage of something else besides the data to check or as a comparison of the data (Miles and Huberman,1994). To analyse data from the interviews and observations, thematic analysis was utilized. The researchers looked at the data carefully to look for the common themes that appear repeatedly from the data. The data were then grouped into categories. Any data that did not belong to any category were considered as individual peculiarity or idiosyncrasy. Once the data obtained, the researchers transcribed, summarized and interpreted them as the basis for understanding the topic being investigated. In this research, the process of analysing the data had been started since data collection was done in a way to sort out which data were essential or not. Creswell (2012) said that qualitative researchers should start thinking and analysing when qualitative research begins. In this study, the researcher used the technique of data analysis based on Miles and Huberman (1994) which is involving three steps: data reduction, data display, and conclusion drawing/verification.

\section{Results and Discussion}

The findings from the observations, interviews, and documentation related to English teachers' problems in applying suggested methods by the 2013 curriculum were presented into three major themes based on research questions. The first theme is related to the problems that encountered English teachers. The second theme discusses 
hindering factors that cause the emergence of problems faced. The third theme is regarding how teachers coped with the problems in applying suggested methods in teaching and learning activities.

\section{Problems in the application of the teaching methods suggested by the 2013 curriculum}

\section{The Obstacles in Translating 2013 Curriculum into Instruction}

A number of English teachers acknowledged that the first factor of teaching problems was the inadequate knowledge and skills in carrying out the learning process (Oktavianti, 2018). It is related to the teaching models that teachers used, whereby in the 2013 curriculum learning activity, teachers should implement the scientific approach in learning models. As the scientific approach was developed based on the concept of the research, the learning process should follow the research-like activities, such as covering observing, questioning, exploring, associating, and communicating to find the new knowledge (Kasim et al., 2017). Teachers' unfamiliarity with the research-like activities was seemingly attributed to the emergence of such problem.

The data from the observations also revealed a similar result. Out of the total nine observations, it was noted that not all teachers applied the teaching methods suggested by the 2013 curriculum. The teachers still got the problems in applying the methods as they admitted in the interviews. The examples for this were found from the classes taught by T2 from SMPX, and T5 from SMPY. These teachers directly explained the learning materials, gave tasks, and checked the works. They did not follow the procedures of scientific approach from the beginning to the last stage. Similarly, this happened to T1 from SMPX and T4 from SMPY who partially finished their teaching activities up to the collecting stage. They did not complete the whole teaching stages of problem based-learning steps.

In analysing the document, researchers did not find new insight since most of the documents were similar to one to another. The follow up interview revealed that most of the teachers used the lesson plans from Subject Teachers Conference or in Bahasa Indonesia, Musyawarah Guru Mata Pelajaran (MGMP). 
"I used the lesson plan from MGMP that had been shared among the English teachers.". T6SMPY

"Sometimes, the lesson plan did not fully cover the material in the handbook,..." T4SMPY.

This illustrates the complexity of the application of the current curriculum. Other data show that teachers tended to emulate the wide spread lesson plans in MGMP that might have been incomprehensive and inapplicable to any situation. Another problem related to teachers' understanding of the teaching methods that appeared from the data was the unsuitability of the teaching methods. In the teaching process, the teachers were noted to give very little attention to the learning stages related to teaching methods in the 2013 curriculum. Hence, the lessons' delivery seemed half-done using scientific approach. This might have happened due to their lack of knowledge about the scientific learning methods, and incapability to elaborate the learning material at the conceptual and implementation level of the 2013 curriculum. At this point, the data confirm the proposition postulated by Darling et.al (2005) about teachers' needs to have solid understanding on teaching learning methods and material mastery. In many ways the teachers under investigation still did not fully understand how they should conduct each step of teaching methods based on the Scientific Approach in the appropriate teaching activities. The result of this study was in line with that of reported by Soepriyanti \& Waluyo, (2019): the teachers' readiness became the stumbling block to the implementation of the new curriculum.

Participants of this study were aware that they could not fully deploy all stages in scientific approach as they perceived that they lacked knowledge of carrying out some of the stages as what Zaim (2017) uncovered. Below is some of the evidence:

"The observing, questioning and associating stages were the hardest thing to do on a scientific approach." T6 SMPY

"The teacher is unable to integrate learning tools for certain skills, so that they often experience obstacles. This causes them to shift into conventional learning, i.e. lecturing method". T1SMPX

The above quotations insinuate that teachers admitted that the major obstacle was to lead the students to actively take part in the learning process as the owner of learning. They likely had shortage of idea in facilitating their students to observe, question, and associate the materials effectively. On top, how to integrate the domain skills i.e. cognitive, attitude and skills was also a serious challenge for them. This disadvantage 
condition seemed affect their willingness to apply this curriculum. In response, the tended to shift the instruction into conventional way .

In the same vein, the data from the observation also showed similar results. It indicated that not all teachers conducted the instruction that contained the stages of scientific approach, especially when guiding the students as a centre of learning. For instance, the data show that T6 from SMPY and T8 from SMPZ still played their dominant roles as the owner of knowledge during the instruction process. They did not give adequate opportunity for students to think, look for, and give opinions related to the topics being learned. The essential part of the scientific approach was neglected. Consequently, this led the class instruction was not congruent with objectives of 2013 Curriculum.. Thus, the claim that scientific approach in the 2013 curriculum can facilitate independent learning and stimulate students' creativity (Sulistyo, et al, 2020) would only be an abstract discourse in this context.

Pertaining to the complexity of using the teaching procedures contained in the 2013 Curriculum, a number of participants expressed some impediments in deploying assessment based on 2013 curriculum. Some of their responses were presented below.

"I find it difficult to apply an assessment because I am not familiar with the assessment system, because there are many types of assessment and assessment instruments that must be filled." T6SMPY

"Carry out learning fully based on the 2013 curriculum and assessment that includes knowledge, attitudes and skills is difficult to do simultaneously." T8SMPZ

The above quotations show that teachers realized that they still faced inconvenience in assessing the whole domains of instruction, especially measuring the skill and attitude domain during the instruction time. The observation shows, for example, T3 from SMPX only used cognitive assessment in the end of class. Similarly, T5 from SMPY did not make the skills assessment. 6 out of 9 teachers only focused on cognitive assessment. In the analysis the documents, it was found out that most of the teachers put the rubrics of three domains assessment. They wrote the rubrics perfectly in the lesson plan. However, when it came to the class, some parts of the assessment were not included. It is evidence from the data that authentic assessment in the curriculum 2013 remained problematic for some teachers. This finding is equivalent with Darsih (2014), Retnawati, Hadi, \&Nugraha (2016), and Suratri's (2018) works. It was reported that the 
teacher had difficulties in developing the instrument of attitude, implementing the authentic assessment, formulating the indicators, designing the assessment rubric for the skills, and gathering the scores from multiple measurement techniques.

\section{Students' Lack of Motivation and Independence}

The second category of problems deals with students' lack of motivation and independence to learn English throughout teaching methods suggested by the 2013 curriculum. The result of the interviews indicates many teachers complained that most of students showed little interest in the learning activities devised by the teacher. Below are some samples of teachers' concerns about the use of new teaching methods as suggested by 2013 Curriculum :

"Sometimes few numbers of students are so enthusiastic about participating in the classroom activities, but in general they show little interest."T1SMPX.

"Students are not willing to listen. Some even do not take part in my class.”T2 SMPX.

"When I asked students to find a problem in problem-based learning, they had not much motivation. Students give up before starting." T7SMPX.

"When I told them to identify a problem in learning material, they had less motivation to do it. So, despite the variety of methods I use, students tend to give up first." T9SMPZ.

Relatedly, the result of the observations was in accord with what teachers had expressed in the interview. The observation data indicates that most students showed little interest and made a disruption in the classroom when the teaching-learning process happened. Students tended to have lack of motivation to learn. They chatted with their classmates or ignored the teachers' instruction.

Among the three grades, the problems related to students' engagement were more frequently found in grade seven in which they had less exposure to use critical thinking compared to the higher grades. The data analysis reveals that many teachers teaching grade 7 got difficulties in applying the four competencies (critical thinking, creative thinking, communicating, and collaborating) and higher-order thinking skills (HOTS) in the English language teaching process under the 2013 curriculum. Students' motivation seemed to be the main cause of their lack of participation. Results of this analysis supported Yulia's (2013) research finding. The following interview quotes provided evidence for teachers' complaint on students' participation in the scientific instruction,

"In the problem-based learning activity that I conduct, not all students prepared to read the material first. So there are a lot of students who do not know the materials and do not even read the material, so students do not know what to ask." T4SMPY 
"In carrying out problem-based learning, there are steps where students do the collecting data.

However, I found the data processing was tough for my students." T7SMPZ

This indicated students' role as the main subject of learning was not functioning positively. They had no adequate autonomy in managing their learning. Data observation obtained was congruent with interview data. Many students did not follow learning activity all the way. For example, in SMPX, some students in the classes were confused about following project-based learning. The same things happened to some classes in SMPY. Similarly, in SMPZ, some students were found to be not actively involved in discovery learning. Thus, the expected elements of SCL (Jacobs, Renandya, \& Power, 2016) as the core point of 2013 curriculum cannot be seen in the praxis. This data trigger the raising of some questions whether these students were inactive by nature or they showed little interest and high dependency due to the teachers' teaching practices. As this study was limited to the understanding of teachers' practices, this issue was not addressed in this study. Probably, in the future, a similar study with focus on students' perceptions, problems and challenges needs to be done.

\section{Hindering factors cause the emergence of problems in applying the teaching methods suggested by the 2013 Curriculum}

\section{Teachers' Knowledge, Skills, and Readiness}

The data elicited from the interviews, observations, and documents indicating that the problems experienced by the teachers were rooted from their inadequate knowledge, skills, and readiness to fully apply 2013 curriculum, as recorded in the following excerpt:

\footnotetext{
"I forgot what it is, that 5M name, observing, questioning, etc..". T1 SMPX

"I have ever used problem based-learning, but sometimes in the class, the learning activity just flows regardless of what kinds of methods are used. The important thing is, students are active in following the class." T4 SMPY.

"I have some problem in using problem based-learning on its steps. It is because of my understanding about the way to implement it in the class." T4 SMPY.
}

The quotes above are some of the evidences of English teachers' unreadiness to use the scientific learning models in the 2013 curriculum. This problem causes some difficulties for English teachers to lead the instructional activities accurately in the classroom. This is in line with Sundayana's (2015) claim: teachers' readiness to implement the curriculum is quite vital. It influences teachers' ability to manage the teaching-learning process (Weiner, 2009). On the other hand, students as the subject of learning faced 
confusion to follow the instruction from unreadiness teachers. Unreadiness teachers might not have adequate understanding and skills to provide effective scaffoldings to introduce new materials or teaching methods. They were likely stumped with conventional way of teaching. This might have correlation with what appeared in the previous discussion in which students showed little interest towards the teaching learning process. Further data stated as follows,

"Practically, I am supposed to use teaching methods based on the 2013 curriculum. Regardless of its particular models, I have been teaching my students with the flow. I don't specify for myself whether I use this method or any other." T5SMPY

"I only used the scientific learning models in a particular material. Since the types of learning model are quite new, I need some times to adapt. T3SMPX

Those expressions signify that the teachers' ability to carry out the scientific learning was not sufficient. This is in contrast with the expected norm in which the teachers' role to conduct the instruction related to suggested methods is very essential. Furthermore, it was confirmed that teachers' readiness such as having ability to design the classroom activities allows students to be active learners (Sulistyo et al., 2020).

The data from the observation also voiced the conformity. Some teachers tended to lead the instruction unproperly. Teachers still did not apply the appropriate teaching methods as they have already written in the lesson plan. For instance, T7 and T8 from SMPY just delivered the task and discussed the materials with their students without using detail procedures of scientific approach. In analysing the document, researchers still found unsuitability between lesson plan and implementation especially in the part of teaching methods suggested by the 2013 curriculum.

\section{Inadequate Support of Teaching Tools and Incomprehensive Teachers Professional Development Program}

The less varied use of teaching media was also an impediment in learning activity using the 2013 curriculum (Ahmad, 2014) because the 2013 curriculum demands to use diverse media and other tools to support student learning. However, the observations uncovered the lack of IT use in the instructions. 7 out of 9 participants did not provide equipped teaching tools. They relied on the use of textbooks and handbooks. Hence, the teaching-learning atmosphere tended to be monotonous consisting of open-read-answer 
cycles and then repeat. This might be one factor contributing to students' boredom and demotivation. T7SMPZ expressed,

"I have a lot of teaching materials on the laptop that I took from the internet and YouTube. However, I never use media to illustrate it because the installation process of the LCD is quite complicated."

The teachers saw the use of IT such as LCD in the classroom was not practical requiring them to meet some administrative procedures; borrowing LCD from the central office, bringing it to the class, installing it, and returning it back. This complication had demotivated them from using LCD. This condition would likely affect the effectiveness of teaching learning process. It also can be said that the utilization of other facilities such as internet services and IT-based tools during learning time that can boost students' autonomy to seek more information and engage with the materials (Khotimah et al., 2019) might not be happening in this such learning atmosphere. Therefore, it suggests that teachers needed adequate practical supporting tools to implement the curriculum better and deliver more interesting instruction.

Another hindering factor was in term of teacher professional development program. They uttered that the programs they participated were not comprehensive in preparing them to be more knowledgeable in translating the curriculum concept into instruction. This similar problem was also became an issue in Ahmad (2014). The materials were limited to the syllabus, lesson plan, and assessment. No follow up materials presenting about operational methods in the instruction was prepared. Only 2 out of 9 participants followed intensive workshops and trainings related to 2013 curriculum. Nevertheless, they also highlighted the same impression in which they needed follow up materials and series of monitoring programs.

\section{Teachers' Efforts to Cope with the Problems of Applying the Teaching Methods Suggested by the 2013 Curriculum}

Dealing with some inconvenience in the 2013 curriculum enactment, 7 out of 9 participants were realized that joining series of teacher professional development would be one common and necessary measure to improve their knowledge, skills, and readiness (Colbert et al, 2008). Having this in mind, several teachers had attempted to improve their knowledge and skills by seeking information about the learning 
approaches suggested from the internet, books, friends, and colleagues (T5 from SMPY and $\mathrm{T} 7$ from SMPZ). In addition, they also participated in sharing forums among English teachers called MGMP, as stated in the following excerpt.

"I tried to cope with student problems in learning with the scientific learning model. For this, I improved my teaching quality gradually by joining some sharing sessions.’T4SMPY.

Some of them asserted that they attended the number of workshops. Most of the teachers pointed out that the presence of MGMP had a positive impact on the teachers facilitating sharing sessions among them. This finding is congruent with the previous study conducted by Soepriyanti \& Waluyo (2019). The data obtained from the interviews indicate that all teachers agreed that teachers needed regular training facilitated by the government in the form of MGMP. However, they voiced that the programs should be set to facilitate them learning how to translate this particular curriculum concept in the instructions. In other words, they need something more operational that directly links to stages in teaching learning process and how to integrate the competence domains. Most of the participants stated that they only participated in workshop related to 2013 curriculum in MGMP once. As mentioned previously, the materials were limited to the syllabus, lesson plan, and assessment. No follow up materials presenting about operational methods in the instruction was included. Only 2 participants followed intensive workshops and trainings. Nevertheless, they also highlighted the same impression in which they needed follow up materials and monitoring program.

\section{Conclusion \& recommendation}

Adapting to a new educational curriculum surely requires persistent efforts and hard work in socializing and monitoring its enactment. Series of studies urgently needed to better understand on what is happening in the praxis. This study was in attempt to investigate English teachers' problems, hindering factors, and the way teachers coped with problems in the enactment of the 2013 curriculum. The findings confirmed that English teachers experienced some delinquent setback in translating the concept of 2013 curriculum into instruction. This is closely related to how they teach using suggested teaching stages, integrating intended domains of competence, and conducting authentic assessment. Furthermore, students' lack of motivation and autonomy was also a sizeable 
impediment in the enactment of 2013 curriculum. In relation to this, the empirical data point out that teachers' inadequate knowledge, skills, and readiness to deploy the intended curriculum, short support of practical teaching tools, and incomprehensive teachers professional development program were likely to be the main hindering factors to effectively put the curriculum into operation. Having these problems, the teachers undertook personal initiative to seek related sources to support their teaching praxis. Also, they participated in regular sharing session of MGMP. This finding in eastern part of Indonesia is quite distinct from what happened in Ratnaningsih's study (2017) in Bandung, a western part of Indonesia. In her case study, she found that teachers could enact the 2013 curriculum effectively. This calls for some further investigations on the factors contributing to the revealed differences.

Considering those findings and the understanding that the scientific approach in the 2013 curriculum potentially to create meaningful instruction, some recommendations are proposed to attain the teaching praxis refinement. First proposal goes to pre-service and in-service teachers' professional development program. The content of this particular program should facilitate pre-service or in-service teachers to not only fully understand the concept but also to be able to implement the whole aspects of learning framework starting from preparation, implementation, and evaluation. Second, the teachers as the key feature of teaching learning process should strive on becoming a more autonomous teachers by having strong curiosity and passion to use their agency in developing their quality of either personal or professional works. Additionally, further research on understanding students' belief and perception in response to the 2013 curriculum deployment is worth conducting to come to a more comprehensive understanding.

\section{Acknowledgment}

We would like to extend our gratitude to the principals who have given access and permission to conduct this study. Also, for the participants who were voluntarily involved in this study. 


\section{References}

Ahmad, D. (2014). Understanding the 2013 Curriculum of English Teaching Through the Teachers' and Policymakers' Perspectives. International Journal of Enhanced Research in Educational Development (IJERED), 2(4), 6-15.

Colbert, J. A., Brown, R. S., Choi, H., \& Thomas, S. (2008). An investigation of the impacts of teacher-driven professional development on pedagogy and student learning. Teacher Education Quarterly, 35(2), 135-154.

Creswell, J. W. (2012). Educational Research: Planning, Conducting and

Evaluating Quantitative and Qualitative Research (4th ed.). Boston, MA: Pearson.

Darling-Hammond, L., Bransford, J. \& Le Page, P. (2005). Introduction: Preparing teachers for a changing world. In Darling Hammond, L. \& Bransford, J. (Eds.). San Fransisco: Jossey-Bass Publisher, 1-39.

Darsih, E. (2014). Indonesian EFL teachers' perception on the implementation of the 2013 English curriculum. English Review: Journal of English Education, (2) 2, 192-199.

Ekawati, Y.N. (2016). The implementation of curriculum 2013: a case study of English teachers' experience at SMA lab school in Indonesia. ELLD Journal, 7(1), 84-90.

Felder, R. M., \& Brent, R. (1996). Navigating the bumpy road to student-centered instruction. College Teaching, 44, 43-47.

Jacobs, G. M., Renandya, W. A., \& Power, M. A. (2016). Simple, powerful strategies for student centred learning. New York: Springer.

Jacobs, G.M. \& Renandya, . A. (2016). Student-centred learning in ELT. In Willy A. Renandya \& Handoyo Puji Widodo (Eds). English language teaching today (pp.13-23). Switzerland: Springer.

Kasim, U., Zulfikar, T., \&Nasriati, N. (2017). Classroom Practice: Applying the Scientific Approach Based on the 2013 Curriculum. English Education Journal, 8(4), 418-535.

Kemendikbud (2013). Materi Pelatihan Guru Implementasi Kurikulum 2013 SMP/MTs. Jakarta: Kementrian Pendidikan dan Kebudayaan.

Khotimah, K., Widiati, U., Mustofa, M., \& Ubaidillah, M. F. (2019). Autonomous English learning: Teachers' and students' perceptions. Indonesian Journal of Applied Linguistics, 9(2), 371-381.

Kielmann, K., Cataldo, F. and Seeley, J. (2012) .Introduction to Qualitative Research Methodology:A Training Manual, produced with the support of the Department for International Development (DfID), UK, under the Evidence for Action Ressearch Programme Consortium on HIV Treatment and Care (2006-2011).

Miles, M. B., \& Huberman, A. M. 1994. An Expanded Sourcebook Qualitative Data Analysis (2nd ed.). London: Sage Publication.

Natasa, P. 2011. The meaning of teacher competence in contexts of change. Nederland Print: Zuidam Uith of Drukkerijen ISBN/EAN: 978-90-393-5695-1.

Oktavianti, T. (2018). Teachers' Difficulties in Teaching English Using Scientific Approach: A Study at Public Senior High Schools in Mataram (Unpublished undergraduate thesis), Universitas Mataram, Indonesia. 
Prihantoro, C. Rudy. (2015). The perspective of curriculum in Indonesia on environmental education. International Journal of Research Studies in Education, $4(1), 77-83$

Regulation of the Ministry of Education and Culture in Indonesia No. 81a of 2013 on the Implementation of the General Guidelines Curriculum. Jakarta: BSNP Indonesia.

Retnawati, H., Hadi, S., \& Nugraha, A. C. (2016). Vocational High School Teachers' Difficulties in Implementing the Assessment in Curriculum 2013 in Yogyakarta Province of Indonesia. International Journal of Instruction, 9(1), 33-48.

Ratnaningsih, Sri. (2017). Scientific approach of 2013 curriculum: teachers' implementation in English language teaching. ENGLISH REVIEW: Journal of English Education, 6(1), 33-40.

Soepriyanti, H., \&Waluyo, U. (2019). Barriers to the implementation of the 2013 English curriculum in high schools in Mataram City: mapping teachers' problems, needs, and supplementary literacy materials for the 2013 English curriculum. In Proceedings of the 65th TEFL in International Conference (65)1, 446-452.

Sulistyo, U., Juwita, M., Agustina, P. S., Astini, S., Anwar, K., \& Wiryotinoyo, M. (2020). What Benefits Students can Take? Portraying the Implementation of EFL Curriculum in Indonesia Through Phenomenological Lens. Ilköğretim OnlineElementary Education Online, 19(3), 1487-1497.

Sundayana, W. (2015). Readiness and Competence of Senior High School English Teachers to Implement Curriculum 2013. Indonesian Journal of Applied Linguistics, 5(1), 28-35.

Thanh, P.T. (2010). Implementing a Student-Centered Learning Approach at Vietnamese Higher Education Institutions: Barriers under Layers of Casual Layered Analysis (CLA). Journal of Futures Studies, 15(1), 21-38.

Wahyudin, AY. \& Sukyadi, D. (2015). A closer look at he Implementation of the Curriculum 2013 in Indonesia: Should the Scientific Approach Be Used in EFL Classroom? RJES, 2(2), 56-70.

Weiner, B. J. (2009). A Theory of Organizational Readiness for Change. Implementation Science, 4(67), 1-9.

Widodo. (2015). Newest issues for curriculum reform in Indonesia (2013). Presented at APEC-Tsukuba International Conference University of Tsukuba, Tokyo: Japan.

Yin, Robert. K. (2018). Case Study Research and Application Design and Methods $6^{\text {th }}$ Edition. Thousand Oaks, California: Sage Publications, Inc.

Yulia, Y. (2013). Teaching Challenges in Indonesia: Motivating Students and Teachers' classroom Language. Indonesian Journal of Applied Linguistics, 3(1), 1-16.

Zaim, M. (2017). Implementing Scientific Approach to Teach English at Senior High School in Indonesia. Asian Social Science, 13(2), 33-40.

\title{
Conflict of Interest
}

No potential conflict of interest is reported.

\begin{abstract}
About authors
Susmalinda Misbah is a student of English study program at the faculty of a teacher of English education, Mataram University.
\end{abstract}


Untung Waluyo is a senior lecturer in the English Department of School of Languages and Arts and Graduate Program of English Language Education, University of Mataram. He received his Bachelor degree in TEFL from Malang State University (1986); MA in General Linguistics from Ohio University, USA (1994) and PhD in language education from University of the Sunshine Coast, Queensland, Australia (2013). His main interests, among other things, are adult literacy, language policy, curriculum and materials development, and teacher professional development.

Khusnul Khotimah, the corresponding author, is a faculty member of English Education Department of Universitas Mataram. She earned her Master's degree from Universitas Negeri Malang (UM), majoring in ELT. Her academic interests include TEFL, Autonomous Learning, Teacher Professional Development, and TPACK.

https://orcid.org/0000-0002-5309-443X 